\title{
Analysis of born globals internationalisation strategy and partnerships
}

\author{
André Luís Figueiredo Santana Dourado* \\ Capitão Antônio Justino Falleiros, \\ 1015, Ituverava, São Paulo, 14500-000, Brazil \\ Email: andreluisfsd@gmail.com \\ *Corresponding author

\section{Mariane Figueira and Cleber Carvalho de Castro}

\author{
Management and Economics Department, \\ Lavras Federal University, \\ Lavras, Minas Gerais, Brazil \\ Email: mariane.figueira@gmail.com \\ Email: clebercastrouai@gmail.com
}

\begin{abstract}
The specific objectives of this study include characterising the born globals founders' profile, identifying the factors that lead the companies to globalise, identifying the reasons of choosing to enter certain countries, verifying how the internationalisation strategic behaviour of born globals had been modified through the years, as well as verifying the role that partnerships represented to born globals. Three organisations from Brazil and Italy were analysed. Interviews were carried out with the organisations' stakeholders through a semi-structured questionnaire previously elaborated. All the interviews were recorded and then transcribed and submitted to content analysis. The study helped clarify some topics related to the role played by partnerships and the founders' profile, more specifically, the temporal aspect of partnerships and the necessary entrepreneur profile of founders. Finally, the study has also found that some concepts in the literature of born globals are not in agreement with the results from the sample analysed.
\end{abstract}

Keywords: internationalisation; strategy; networks.

Reference to this paper should be made as follows: Dourado, A.L.F.S., Figueira, M. and de Castro, C.C. (2019) 'Analysis of born globals internationalisation strategy and partnerships', Int. J. Strategic Business Alliances, Vol. 6, No. 4, pp.217-232.

Biographical notes: André Luís Figueiredo Santana Dourado obtained his Bachelor's and Master's in Management in the Federal University of Lavras. His research focuses are international businesses, strategy and networks.

Mariane Figueira is a management teacher in the Federal University of Lavras. Her research focus is international businesses.

Cleber Carvalho de Castro is a management teacher in the Federal University of Lavras. His research focus is networks. 


\section{Introduction}

Research on born globals, also labelled as born internationals, international new ventures, global start-ups, among other terms, and their internationalisation processes have received considerable attention in the past two decades, however, without reaching a conclusion or a theoretical unified model that allows identifying common patterns and characteristics of those firms after some years of operation (Martin and Oscar, 2015).

Born globals can be defined as companies that, although small, are competitive against larger established players and also manage profitable and fast-growing global business systems in a way that seemed impossible a few decades ago (Rennie, 1993).

According to Prange and Verdier (2011), dynamic capabilities built and nurtured by international entrepreneur founders would be a key factor supporting the early internationalisation process. Acedo and Jones (2007) have pointed out that the characteristics of the founder strongly influence if new firms become internationalised in their beginning.

Nevertheless, born globals have received much attention, literature on strategic management and international business has pointed out some shortcomings which deserve further examination.

Carneiro and Dib (2007) addressed two gaps in the study of born globals, the first being the absence of an analysis of the profile and behaviour of decision makers, and the second, the absence of post-expansion international studies related to the management and integration of international operations.

Martin and Oscar (2015) point a substantial absence of studies on born globals that analyse the performance of this type of firm after one year of its foundation. Although the present study does not use a quantitative approach and does not focus on the performance of this type of organisation, the gap mentioned was used as the basis for an exploratory analysis of the behaviour of this type of organisation after one year of its foundation.

Finally, Falize and Coeurderoy (2012) stress a research gap regarding the lack of analysis on the role of networks in small and medium-sized internationalised companies.

Three shortcomings were selected: the lack of studies on the profile and behaviour of decision-makers, the lack of studies on international management and integration processes, and the lack of studies on the role of networks in internationalised small and medium-sized enterprises.

Besides the aforementioned gaps, the management strategic behaviour and its relationship with networks, more precisely partnerships, are also relevant on this analysis because in born globals they tend to be very specific, especially in the beginning, since as Reuber and Fischer (1997) noted, managers with previous international experience uses more strategic foreign partners and take less time to achieve foreign sales after starting up business.

Briefly, the research question attempting to fill the gaps pointed out would be the following: what is the strategic behaviour of internationalisation of born globals and what is the role played of partnerships?

The main objective of the present paper, therefore, is precisely to evaluate the strategic behaviour of born globals regarding internationalisation and the role of partnerships in such a process.

Three born globals from different sectors, one from Brazil e two from Italy, were chosen as case units to allow the analysis of the research question. 
According to the Ministry of Commerce, Development, Industry and Foreign Trade (Ministério do Desenvolvimento, Indústria e Comércio Exterior, 2014), Brazil had a share of global exports (FOB values) of $1.22 \%$ in 2014 (last year available on MDIC's website), while the presence of Italy was of $2.8 \%$ in the same period (Italian Trade Agency, 2015). The second difference is economic integration and the adoption of the single currency in the European Union, of which Italy is a member. Mercosur has not yet succeeded in achieving full economic integration, nor does it adopt a single currency in the region.

The interviews carried out in this research with stake holders of the selected companies focused mainly on the analysis of aspects regarding strategy development, networks and learning process.

The present study intends to contribute to literature that has already been built by uniting theoretical and empirical analysis. As Sharma and Blomstermo (2003) have argued much of the research on the born globals area is empirical; however, much of the research is not theory-based. Focusing these research gaps, the present study also contributes theoretically and empirically to this theme.

As a means of contributing to private firms, the present study highlights the analysis of the behaviour of organisation and stakeholders as possible factors which might signal the success or greater speed in the initial process of internationalisation. Gerschewski et al. (2015) have also point out a more specific choice of how born globals choose to approach foreign markets as a possible contribution to managers, since the choices made at entry have a direct relation to future success.

The present study is organised in four sections besides this introduction. Section 2 will address the study's theoretical underpinning, and Section 3 will address research method applied. Section 4 will address results and discussion and Section 5 will address the conclusions.

\section{Theoretical underpinning}

What differs born globals from other kind of companies, according to Knight and Cavusgil (2009) it's his international origin, with a management that sustain a global focus and also the commitment of certain kind of company resources in international activities.

In contrast with the traditional business standard that operates on its home country for many years and gradually evolves into an international business, born globals begin with a vision of the world without borders and develop the necessary strategies for expansion in foreign territory or in a country close to its foundation.

Time is also a factor that must be taken into account for the fact that interferes directly with the process of internationalisation of companies in the respective countries. Other factors should be included, such as bureaucratic procedures for exporting, and education level of the population, since in born globals might be harmed by environments with a high level of bureaucracy. For Knight and Cavusgil (2009), born globals are naturally more flexible companies, and therefore averse to bureaucracy. 


\subsection{Firms' internationalisation: concepts and models}

A very important aspect to be analysed in the process of internationalisation is the entrepreneurial spirit. A study by Muralidharan and Pathak (2016) highlights that the environment can significantly affect the entrepreneurship process, specifically internationalisation-oriented entrepreneurship, including organisations such as born globals. The authors have stated that three informal institutional aspects help explain international entrepreneurship.

First, a social yearning that encourages or is not hostile to more aggressive domestic entrepreneurship. Second, a social performance orientation that makes entrepreneurs believe that there will be a return through the effort employed and that a more aggressive style will have recognition. And third, personal expression values at the social level that allow individuals to express and go after individual objectives.

This last aspect is related to environments that have an economy in good development and no scarce resources, which helps explain the extension of internationalisation in beginning entrepreneurial firms, since the entrepreneur would not need to worry about its mere survival, which is the case of an unstable nation with a shaken economy.

\subsection{Strategic behaviour}

Being a field where the presence of models is not yet a reality, strategic behaviour of born globals is difficult to define, either because there is not yet a body of literature that defines in a predictable and homogeneous way the types of behaviour of this type of firm or for the shortage of authors that deal with the aspect of the strategy in loco or over time.

According to Reuber and Fischer (1997), in their study of small and medium-sized software companies in Canada, management with international expertise uses more foreign strategic partners and takes less time to achieve sales abroad after starting business. Although a few firms in that study have internationalised soon after foundation, the use of foreign partners and the presence of international experience in the companies that obtained sales abroad earlier is consistent with the characteristics related to international new ventures.

Regarding the decision-making process and the use of external knowledge sources, Luostarinen (1994) assures that family companies are more traditional in the internationalisation process, besides being slower and passive, opting to saturate the internal market before internationalising. The scholar has also stated that this type of company does not use outside knowledge, most notably the experience, even when internal knowledge is insufficient. In non-family businesses, the scholar states that external knowledge is recruited when it is insufficient within the company.

Sharma and Blomstermo (2003) have pointed out that the competitive advantage of these organisations is the intensity of knowledge, and that the ability to recombine current knowledge to develop new products makes born globals' knowledge base transient in their network of relationships, codified and difficult to imitate.

According to the same scholars, it is much more difficult for domestic firms with no international relationships and long domestic experience to change their mental models and processes than it is for a born global, since companies with a long domestic experience may have a much more solid knowledge platform. 


\subsection{Relationships, partnerships, networks and competitivity}

According to Falize and Coeurderoy (2012), in their study of innovation network ties in born globals and born-again globals, international networks for innovative small and medium-sized enterprises can offer a response to the challenge of globalisation, as well as allowing access to knowledge centres and accelerating innovation.

The scholars have point out that difficulties or 'liabilities' related to expansion, scarcity of complementary resources or 'newness', aspects related to the shortage of cultural knowledge of new markets or 'foreignness', besides perceived risk, increase the time necessary to enter a foreign market. These three types of liabilities plus the perceived risk may cause problems related to information, resources and control which international networks can partially solve. International networks can help overcome liabilities and increase the internationalisation speed of born globals.

Kontinen and Ojala (2011), studying small and medium-sized family businesses, demonstrated that network ties are important resources, and that those same firms that did not have ties with networks did recognise the opportunities through weak ties when entering foreign markets.

Sharma and Blomstermo (2003) pointed out that the recognition of international networks as an efficient means of helping small and medium-sized companies with an international orientation enabling them to internationalise more quickly contributes to the theory of networks and the study of international entrepreneurship. The scholars mentioned that it is common in literature to focus more on small and medium-sized enterprises than on formal networks.

Coviello and Munro (1994) carried out a case study of four New Zealand firms in the software industry where every firm was in a stage of mature internationalisation, ranging from 10 to 15 years. The scholars found out that those firms were able to quickly internationalise due to extensive networks already established.

According to Johanson and Vahlne (2009), pre-established contacts in the field of activity targeted by the born global are an important source of information, without however being essential for an accelerated internationalisation process.

The scholars emphasised two aspects faced by born globals during the internationalisation process: 'liability of outsidership' and 'liability of foreignness', respectively.

According to Sharma and Blomstermo (2003), born globals can reduce their risk by entering new markets, gaining knowledge of markets and external customers through their network ties - contacts and relationships.

Weak ties are less complex and costly to maintain, and they do not integrate formal routines of information collection and interpretation, such as market research.

\section{Research method}

The present study is qualitative in nature for the fact that intends to deepen the analysis of the object of study, that is, the companies analysed, focusing on the aspect related to their formation, changes in their strategic character and the role of the partnerships over time.

An exploratory study was developed to allow the analysis of the real context of the object of study without any manipulation by the researcher (Dul and Hak, 2008), which was more adequate to meet the proposed objectives. 


\subsection{Case units}

While born globals are the object of study, the subjects of study are the born globals' stakeholders and employees with more than five years of experience in Italy and Brazil, regardless of the sector of activity.

Dib (2008) exposed the temporal heterogeneity that has been adopted in literature to define born global organisations, reaching up to 15 years after foundation. As the present study does not intend to focus specifically on those aspects related to the foundation characteristics of this type of firm, but rather, on post-expansion aspects, in addition to focusing on firms that have obtained rapid internationalisation, we have adopted the time period of two years maximum, as the criterion for choosing the firms analysed in this study.

Definition of concepts for the present study in order to obtain an adequate evaluation and consequently reliable data was carried out based on an interview script, supplemented by literature.

The choice of companies for this study was based upon the following criteria:

- To be or have been present in more than two foreign countries, either in the form of sales or as a subsidiary.

- To be outside its continent, whether in the form of sales or as a subsidiary.

- To be operating for at least five years.

- To have undergone some internationalisation experience soon after its foundation or at most two years after its foundation.

\subsection{Data collection}

Three interviews were conducted with three organisations from different sectors. Data was collected form the interviews, documentary analysis and exploratory literature review.

Concepts covered in the present study are somewhat broad as the case units, however an interview script approach composed of open questions was efficient both in the definition of the terms by the respondents as well as in the quality of the information obtained. In order to establish a better categorisation of the analysed organisations, Table 1 was elaborated to describe the organisations and respondents.

Table 1 Researched companies' categories

\begin{tabular}{lcccc}
\hline Organisation & Sector & Size & Respondents & Country of origin \\
\hline *Alpha & Food industry & Large & Press Office (E1) & Italy \\
$*$ Beta & Turnkey, & Small & President/Founder (E1), & Italy \\
& interior design & & Financial Dir., Commercial & \\
$*$ Gama & Fashion industry & Small & Dir. and Press Office & Marketing Director/ \\
& & & Co-founder (E1) & Brazil \\
\hline
\end{tabular}

Note: *Fictitious names.

Source: Developed by the authors 
Semi-structured interviews were conducted following a script previously elaborated containing 32 questions, of which two were closed. All interview material was recorded, transcribed and coded. We have also performed a documentary analysis and later validation of the data collected through an exploratory review based on available content on the topic.

The interview script was based upon the questionnaire developed by Scattolin (2012). Nevertheless, the script was altered and adapted to respond to the objectives of the present study.

Martin and Oscar (2015) selected some important variables in the questionnaire used in their study to detect the performance of born globals in the long-term. For the development of the present study six of those variables were chosen to be used in the interview script (with permission). They were adapted to allow the collected data to be more suitable for a qualitative study as the following:

- diversity of entry modes

- number of employees in international activities

- $\quad$ number of foreign languages used

- investment on entry modes

- $\quad$ success on international activities in the last three years

- international profit in the last three years.

Questions were divided into categories in the interview script, following in part Scattolin's (2012) questionnaire, intending to meet the objectives proposed by the present study, such as strategic aspects, internationalisation and networks.

Only two multiple-choice questions from the original questionnaire were maintained, those related to total profit and profit abroad, information necessary for organisations to be classified in the choice criteria.

Some multiple-choice questions and scales of the original questionnaire were transformed into open questions, concerning factors of globalisation, adaptation, and integration of cultures into new markets.

The questionnaire begins with the category 'network, business choices and birth factors', which has no subcategory. In the second category of the interview script related to competitive factors, there is subcategories 'entry' and 'learning and performance'.

The third category is related to company identification and international commitment. The fourth and final category is related to the connection with the national territory.

\subsection{Data analysis}

After conducting the interviews data was transcribed and coded through a thematic content analysis based upon Bardin (2011).

Since the main objective was to evaluate the strategic behaviour of organisations regarding internationalisation and partnerships, it was necessary to analyse the stakeholders' point of view, having in mind they manage and take part in the strategic guidelines of organisations. Besides that, how training and behaviour impacted the organisation's strategy and partnerships was also analysed. 
With the exception of company alpha, it was possible to collect information directly from the most influential stakeholders in the chosen organisations. However, the complementation with the documentary analysis in company alpha was satisfactory to answer the objectives of the present study.

Research data was analysed through a framework elaborated drawing on scholars reviewed in the theoretical underpinning. Categories were created based upon definitions that could help explain both the strategic behaviour of born globals and the other proposed specific objectives. Table 2 has been elaborated to explain the construction of categories that allowed data analysis.

Departing from the interviews transcribed, parts form the text that matched the most the categories mentioned in Table 2 were selected enabling data to be analysed.

Table 2 Theoretical underpinning used to develop data analysis categories

\begin{tabular}{|c|c|}
\hline Category & Theoretical underpinning \\
\hline Entrepreneurship & $\begin{array}{l}\text { Entrepreneurs "exploit change as an opportunity... for a } \\
\text { different business or service" (Drucker, 1987). }\end{array}$ \\
\hline $\begin{array}{l}\text { Previous Experience or not within } \\
\text { the sector }\end{array}$ & $\begin{array}{l}\text { International experienced management are more likely to } \\
\text { make more international partnerships (Reuber and Fischer, } \\
\text { 1997). }\end{array}$ \\
\hline \multirow[t]{2}{*}{$\begin{array}{l}\text { Internationalisation with or } \\
\text { without previous experience in } \\
\text { the area }\end{array}$} & $\begin{array}{l}\text { Product with international excellence and quality are } \\
\text { paramount for the internationalisation (Luostarinen, 1994; } \\
\text { Sharma and Blomstermo, 2003). }\end{array}$ \\
\hline & $\begin{array}{l}\text { Management with international experience utilise more } \\
\text { foreign strategic partners and take less time to achieve } \\
\text { foreign sales after the business foundation (Reuber and } \\
\text { Fischer, 1997). }\end{array}$ \\
\hline $\begin{array}{l}\text { Presence or absence of former } \\
\text { contacts in the sector }\end{array}$ & Psychic distance (Johanson and Paul, 1975). \\
\hline $\begin{array}{l}\text { Liability of outsidership and } \\
\text { liability of Foreignness }\end{array}$ & $\begin{array}{l}\text { Liability of foreignness and liability of outsidership } \\
\text { (Johanson and Vahlne, 2009). }\end{array}$ \\
\hline \multirow[t]{2}{*}{ Strategy formulation } & Strategy is a crafting process (Mintzberg, 2000) \\
\hline & $\begin{array}{l}\text { Family firms are more traditional when it comes to } \\
\text { internationalisation processes (Luostarinen, 1994). }\end{array}$ \\
\hline Learning & $\begin{array}{l}\text { Born globals learning process continues long after its } \\
\text { foundation (Martín and Oscar, 2015). }\end{array}$ \\
\hline Partnerships & $\begin{array}{l}\text { Weak ties provide valuable opportunities when entering } \\
\text { foreign markets (Kontinen and Ojala, 2011). }\end{array}$ \\
\hline
\end{tabular}

Source: Develop by the authors

\section{Results and discussion}

Results have been organised according to the specific objectives proposed. Tables 3 and 4 have been developed drawing on the answers given by the interviewees and guided by the reviewed literature, willing to address the present study's specific objectives.

A summary table (Table 3) specifies how the specific objectives match each one of the organisations researched. 
Drawing on Table 3 it is possible to notice that within each one of the objectives there are differences between the analysed companies, which will be explained in more detail on the next section.

Table 3 Summary of the specific objectives

\begin{tabular}{|c|c|c|c|c|}
\hline \multicolumn{2}{|c|}{ Specific objectives } & \multirow{2}{*}{$\begin{array}{c}\text { Alpha } \\
\text { Entrepreneur }\end{array}$} & \multirow{2}{*}{$\begin{array}{c}\text { Beta } \\
\text { Aggressive } \\
\text { entrepreneur }\end{array}$} & \multirow{2}{*}{$\begin{array}{c}\text { Gama } \\
\text { Entrepreneur }\end{array}$} \\
\hline 1 & Profile of the founders & & & \\
\hline 2 & Globalisation factors & $\begin{array}{l}\text { Entrepreneurial } \\
\text { spirit }\end{array}$ & Environment & Partnership \\
\hline 3 & $\begin{array}{l}\text { Reasons for choosing the } \\
\text { market }\end{array}$ & Brand spreading & Previous contact & Partnership \\
\hline 4 & $\begin{array}{l}\text { Changes in strategic } \\
\text { behaviour over time }\end{array}$ & Few changes & Not planned & Few changes \\
\hline 5 & Networks and partnerships & $\begin{array}{l}\text { Has and knows } \\
\text { how to use }\end{array}$ & $\begin{array}{c}\text { Closed, does not } \\
\text { use }\end{array}$ & $\begin{array}{l}\text { Informal, not so } \\
\text { much used }\end{array}$ \\
\hline
\end{tabular}

Source: Develop by the authors

\subsection{Profile of the analysed companies' founders}

The first category covered in the content analysis was the entrepreneurial profile, as pointed out on Table 4.

Having in mind that the presence or the absence of previous experience in the sector is an aspect that is closely related to the formation of the behaviour of born globals' founders, this theme was one of the most relevant categories for understanding the strategic behaviour of born globals. It was possible to note that company gama did not have a manager with previous international experience, not even in the sector or product with which it was working. This lack of experience should be taken as very important because it contradicts in part Reuber and Fischer (1997), which affirm that only a manager with international experience is prone to develop more international partnerships.

Within the analysed companies, all of the interviewees presented foreign language knowledge, regardless of their function or position, which indicates that this can be a differential or even a necessity for organisations of this type.

However, not all of them had experience in the current field of activity.

Within organisation alpha, the respondent had fluency in foreign languages. Nevertheless, she was neither a leader nor a founder of the company. For that fact, interpretation of the information from organisation alpha was complemented by a documentary analysis. In the documents of organisation alpha, it was possible to verify that the founder of the organisation already had experience in retail when it decided to found the company.

Considering beta, the profile of the founder, most influential stakeholder in that company, was the closest to Drucker (1987) and Martin and Oscar (2015) classic entrepreneur profile. Although he had experience in the sector in which he operates and fluency in five languages, conditions for the founding of the company were adverse.

Regarding gama, the analysed stakeholder, co-founder of that company, does not follow much of the founder's profile widely spread in the literature. She has knowledge 
in only one foreign language and does not have prior experience in the field in which she is currently operating. She has only taken one fashion design course, but did not work in that field, and did not have contacts in the sector until the foundation moment, which could have facilitated the process of the company's internationalisation.

Given the absence of both previous experience and contacts, the profile of the founder of gama was also quite entrepreneurial and not so much risk-averse.

Analysing Table 5, the preponderance of the entrepreneurial profile is perceptible. Such behaviour allowed the organisations to be more daring than usual, either in the fact that an organisation can start the activities in a new sector, which is the case of Alpha, even with no resources, which is the case of beta or with no previous contacts which is the case of gama.

Table 4 Categories concerning the profile of the analysed companies' founders

\begin{tabular}{|c|c|c|}
\hline Category & Description & Examples \\
\hline Entrepreneurship & $\begin{array}{l}\text { Entrepreneurial spirit, operations in } \\
\text { risky conditions or at a high-risk } \\
\text { sector }\end{array}$ & $\begin{array}{l}\text { "...I build really without one penny } \\
\text { in the pocket, more or less, so it } \\
\text { was a big challenge..." (E1 - Beta) }\end{array}$ \\
\hline \multirow[t]{2}{*}{$\begin{array}{l}\text { Previous } \\
\text { experience in the } \\
\text { sector }\end{array}$} & $\begin{array}{l}\text { Previous job related to the current } \\
\text { firm's sector or entirely new sector }\end{array}$ & $\begin{array}{l}\text { “...I couldn’t ever build this } \\
\text { company without the previous } \\
\text { experience...”(E1 - Beta) }\end{array}$ \\
\hline & & $\begin{array}{l}\text { "I have never worked in this sector } \\
\text { before, we have been operating } \\
\text { since } 2010 \text { " (E1 - Gama) }\end{array}$ \\
\hline
\end{tabular}

Source: Develop by the authors

Table 5 Founders' profile

\begin{tabular}{ll}
\hline Organisation & \multicolumn{1}{c}{ Founder's profile } \\
\hline Alpha & $\begin{array}{l}\text { Entrepreneur, however, a bit conservative and risk averse. Had previous } \\
\text { experience, but not in the field in which operates. }\end{array}$ \\
Beta & $\begin{array}{l}\text { Entrepreneur and not risk averse. Had prior experience in the field in which } \\
\text { operates. }\end{array}$ \\
Eama & $\begin{array}{l}\text { Entrepreneur and not risk averse. Had no previous experience in the field in } \\
\text { which operates. }\end{array}$ \\
\hline
\end{tabular}

Source: Develop by the authors

According to Muralidharan and Pathak (2016), in fact there is a convergence of factors that help explain international entrepreneurship. The three aspects, social yearning, performance orientation and values of social expression, most of them were present in some sort in the three organisations studied.

Considering alpha and beta, the three aspects were preponderant, since the environment was favourable to the investment and commitment of the founders. In addition there was no bureaucratic impediment. The founders have also had a strong individual vision for entrepreneurship.

On the other hand, regarding gama, the orientation of social performance was absent once the environment was a more bureaucratic one. Nonetheless, the social longing favourable to entrepreneurship and the values of social expression stemming from the co-founder's vision were present. 


\subsection{Factors that led companies to globalise}

Table 6 shows a relevant category related to the internationalisation factor that deals with the presence or the absence of prior experience in the sector.

Alpha had as a main factor of internationalisation the entrepreneurial spirit of the founder. Because it already has sufficient financial resources and retail knowledge, its susceptibility to tolerating risks was much higher. The founder, however, preferred to be cautious about the product marketed, as he did not have so much knowledge about it. To overcome this obstacle, the founder joined a non-profit foundation in the food area to gain more knowledge about the product and meet potential suppliers.

Table 6 Category related to the internationalisation

\begin{tabular}{lll}
\hline Category & \multicolumn{1}{c}{ Description } & \multicolumn{1}{c}{ Examples } \\
\hline $\begin{array}{l}\text { Internationalisation in } \\
\text { an area with or without } \\
\text { previous experience }\end{array}$ & $\begin{array}{l}\text { Absence or presence of } \\
\text { knowledge about } \\
\text { internationalisation } \\
\text { processes in the sector where } \\
\text { it operates }\end{array}$ & $\begin{array}{l}\text { of the companies in this group, which } \\
\text { doing now." (E1 - Beta) }\end{array}$ \\
& $\begin{array}{l}\text { "We have been chosen. We did not } \\
\text { choose this internationalization" } \\
\text { (E1 - Gama) }\end{array}$ \\
\hline
\end{tabular}

Source: Develop by the authors

For beta the environment, more specifically the geopolitical and historical contexts played an important role in the internationalisation process. Because the firm is situated in a region which is a few tens of kilometres from the border with an Eastern European country, and, therefore, in a region of strong influence of the Soviet Union, since the foundation of the company was seven months before the fall of the Berlin wall, this event, according to the founder, was one of the main factors that can explain the emergence of the company's global vision.

In the case of gama, an important factor for internationalisation was partnership, due to the opening of the channel provided, which would be virtually impossible to do on its own account due to the lack of resources and contacts of the organisation, a factor pointed out as relevant by Reuber and Fischer (1997).

\subsection{Reasons for choosing to operate in certain countries}

Local market knowledge acquired through contacts and/or partnerships is a relevant factor as it immediately interferes in the choice of the market where the company can operate, thus forming part of the organisation's strategic behaviour related to internationalisation. On Table 7, such concepts are grouped into two categories, one focused on liabilities and the other focused on the presence or absence of previous contacts in the sector in which the company operates.

Although the category dealing with previous contacts already includes much of the concept dealt with in the liability of outsidership, it does not include the liability of foreignness, which deals with language, laws and rules of the country in which the organisation intends initiate some process of internationalisation. This category is perhaps the most important, since in all of the analysed organisations the presence of both concepts was verified. 
Table $7 \quad$ Motives of choice

\begin{tabular}{lll}
\hline Category & \multicolumn{1}{c}{ Description } & \multicolumn{1}{c}{ Examples } \\
\hline $\begin{array}{l}\text { Presence or absence of } \\
\text { previous contacts in the } \\
\text { sector of operation }\end{array}$ & $\begin{array}{l}\text { To verify if there were contacts in } \\
\text { the current sector of operation } \\
\text { prior to the founding of the } \\
\text { company }\end{array}$ & $\begin{array}{l}\text { "...there was a contact we had, } \\
\text { Ihe managers..." (E1 - Beta) } \\
\text { the mal contacts with } \\
\text { "No, we didn't have it. We had } \\
\text { nothing". (E1 - Gama) }\end{array}$ \\
$\begin{array}{l}\text { Liability of outsidership } \\
\text { and Liability of } \\
\text { foreignness }\end{array}$ & $\begin{array}{l}\text { Presence or absence of either } \\
\text { knowledge of contacts and } \\
\text { business know-how, or laws, rules } \\
\text { and culture of the market where } \\
\text { the company currently operates }\end{array}$ & $\begin{array}{l}\text { "Language yes, it is obvious, } \\
\text { but no laws and no rules" } \\
\text { (E1 - Gama) }\end{array}$ \\
\hline
\end{tabular}

Source: Develop by the authors

Organisation beta had its first internationalisation process and consequently the choice of the first country directly influenced by a previous contact. The guiding motive was a contact made before the foundation of the company, while the founder worked in another company that operated in the same sector managed by the current organisation. At alpha the main reason for the choice of the first countries of operation was given as an effort to spread the organisation's brand. In gama's case, it became clear that the main reason was a partnership with a government agency that made it possible for the company to have greater visibility in an international fair that allowed greater sales.

\subsection{Changing strategic behaviour over the years}

Both strategy formulation and learning were relevant categories to better understand how change occurred within the strategic behaviour in the analysed organisations. Both categories are dealt with in Table 8.

Table 8 Changing strategic behaviour

\begin{tabular}{lll}
\hline Category & \multicolumn{1}{c}{ Description } & \multicolumn{1}{c}{ Examples } \\
\hline Strategy formulation & $\begin{array}{l}\text { Formal decision-making model, } \\
\text { family firm, short or long-term } \\
\text { planning }\end{array}$ & $\begin{array}{l}\text { "...they plan the strategy in only } \\
\text { of a few months..." (E1 - Alpha) }\end{array}$ \\
Learning & $\begin{array}{l}\text { How the organisation acquires } \\
\text { and implements new knowledge } \\
\text { acquired during the } \\
\text { internationalisation process }\end{array}$ & $\begin{array}{l}\text { "Mainly advisors in France and } \\
\text { businessman warned me: "be } \\
\text { careful, don't take a local } \\
\text { shareholder in China." Same } \\
\text { thing they told me for India.... } \\
\text { (E1 - Beta) }\end{array}$ \\
\hline
\end{tabular}

Source: Develop by the authors

Beta, for example, despite being a family firm, used outside resources to be informed about how to operate in markets outside its country, which consequently changed its mode of entry in some countries.

Considering alpha, it can be observed that the internationalisation strategy adopted few changes over time. Although the researchers did not have access to the main stakeholders, it was possible to detect that the planning and decision-making process 
related to international expansion follow a formal process guided by the organisation's leadership.

In the documentary analysis of organisation alpha, the director of a unit of the organisation located at an Asian country mentioned that the selection of products marketed is conducted by the headquarters, except for the commercialisation of local products. There is no difference in the packaging of the products sold.

Another interesting point is related to the training of the managers responsible for the units outside the country. In the documentary analysis, it was clear that the managers are trained at the headquarters and then are assigned to other units outside the country. The same procedure is adopted for the managers of the other units within Italy.

Regarding beta, the accelerated international expansion of the organisation was not planned in the beginning. However, with the increase in the number of customers and in businesses, changes of strategy became clear. An interesting aspect is that although it is a family business, it contradicts many aspects analysed by Luostarinen (1994), which states that family businesses are little internationalised, and that when this type of firm internationalises they carry out the operation slowly and passively, having a longer domestic period and worse results than small non-family businesses.

Considering gama, we did not find any formal changes in the strategy of the company throughout time. Nevertheless, it has had some changes in its organisational framework, such as the entry of a new partner.

\subsection{The role of partnerships for the born globals analysed}

Only at organisation gama we could observe a very influential partnership in the internationalisation process, as is shown in Table 9.

Alpha was the organisation that most differentiated among the other organisations in relation to their behaviour towards the partners. In an extremely competitive environment, such as the global retail sector, the organisation's innovative business model chooses to treat the small and medium-sized agricultural producers, who are the organisation's main suppliers, in a differentiated way.

By partnering with a non-profit organisation, the company's founder chose to use the organisation's philosophy to help find suppliers for products marketed in its affiliates. In addition to joining a non-profit organisation, the founder chose to buy part of the stake of some suppliers, and in some cases, to buy suppliers, such as the case of a water supplier.

In addition to having this mixed management model aimed at partnering with organisations in the agricultural and food sector, the management of the organisation has the traditional form of a large family business, even without the presence of an organisational chart.

The organisation fits the definition of Luostarinen (1994), which states that large family organisations are internationalised faster than organisations of the same size but that are not family businesses. According to the scholar, this type of organisation appears to gather the strengths of family and non-family businesses by recruiting external human resources to the company for the group's management and to the board of directors, utilising the flexibility and quick reactions of a family business.

In the documentary analysis of organisation alpha, the detail of this process of partnership in management was deepened. In the case of a subsidiary in an Asian country, 
the organisation decided to choose an Italian partner who had already worked with a food company in the country. This partner manages the entire bureaucratic part of the subsidiary. An interesting point is that in addition to that, this manager brought with him Italian employees who speak the language of that Asian country and have experience in that market. In this way, managers are able to overcome both the liability of outsidership and the liability of foreignness, because they can understand laws, rules, local language and culture and, moreover, they can connect to the local market through a partnership that inserts them into the market network, facilitating communication and understanding of how to behave before suppliers, customers and local competitors.

Table 9 Partnerships

\begin{tabular}{|c|c|c|}
\hline Category & Description & Examples \\
\hline \multirow[t]{2}{*}{ Partnerships } & $\begin{array}{l}\text { Partnerships that have affected } \\
\text { in some way the organisation or } \\
\text { process of internationalisation }\end{array}$ & $\begin{array}{l}\text { "...we have joined ABEST, and ABEST is } \\
\text { sponsoring to bring outside buyers to see } \\
\text { the members" (E1 - Gama) }\end{array}$ \\
\hline & & $\begin{array}{l}\text { "...the food in Alpha, there's strategic } \\
\text { partners. It means that slow food helps } \\
\text { Alpha finding the best local and traditional } \\
\text { producers." (E1 - Alpha) }\end{array}$ \\
\hline
\end{tabular}

Source: Develop by the authors

Departing from the data analysed, it is clear that alpha was able to use the network ties in a useful way as stated by Kontinen and Ojala (2011), who demonstrated that network ties are important resources, and weak ties offer valuable opportunities when entering foreign markets. The weak ties that organisation alpha had with its partners in Asia illustrated well this connection observed with literature.

Regarding beta, although there was no system or process of partnerships similar to what was observed at alpha, the organisation has as one of its main assets the long-term relationship with its clients, an asset that, according to the owner, makes it difficult to establish partnerships, since the treatment of its clients is something almost entirely based on trust, an intangible good, difficult to handle by someone who is not family or who has not worked in the company for a long time, thus becoming a hindrance to partnerships, either in shareholding or in the opening of new subsidiaries.

At the same time, as mentioned earlier, beta uses external expertise through temporary partnerships with locals to overcome liability of outsidership and liability of foreignness in the new markets in which it intends to enter.

At gama, partnerships exist more predominantly in informal relationships. The exchange of important information among peers in the industry is recurrent and treated cordially. A clear example analysed would be the non-adoption of formal contracts in the elaboration of product mixes in conjunction with other companies. The partnership with government allowed gama to contact a large client from a foreign country without the knowledge of laws and rules of that country. Nevertheless, the co-founder had no knowledge and contacts in the country of his largest client. The high capillarity of his client's subsidiaries allowed gama to overcome the need, at least while maintaining relations with this client, to make new contacts in the market in which its client operated.

Such capillarity reached by organisation gama through its client exempted gama from the need to have previous contacts in the market where it started to operate. This 
demonstrates that the resources needed to internationalise do not always have to be built before the foundation of the company.

\section{Conclusions}

Drawing on the data analysed, it is possible to verify that some concepts exposed in the born globals' literature are not in agreement with the results found from the analysed sample.

Literature on born globals pointed out basically at small organisations, with founders with extensive previous experience, especially in the international area and/or previous contacts, which would justify an accelerated internationalisation process.

However, other environmental factors, such as the liability of foreignness and the liability of outsidership, have proved to be imperative and sometimes even more important than some factors pointed out in the literature as central to the success not only of born globals, but for any type of organisation that intends to operate in a foreign market.

Returning to the research question, which focused on the strategic behaviour of internationalisation of born globals and the role played of partnerships, it is visible in all of the analysed organisations that strategic behaviour is closely linked to two factors: the environment and the founder, most notably his entrepreneurial spirit. All founders, regardless of their financial situation, took risks in one way or another to start the activities of the organisation. Whether entering a sector that had no experience or starting their activities with little or no available resources, all have effectively taken an initiative with a high degree of risk.

Moreover, the internationalisation process of those organisations followed the path towards entrepreneur behaviour, having a clear influence on the company behaviour itself, meaning most of the time a more aggressive strategy was used, which is itself a clear demonstration of the manager profile.

In the case of partnerships, although they are a somewhat relevant topic in the literature, researchers found that there are different types of partnerships when a temporal analysis is performed. This study found that the relevance of partnerships seems to be higher in the earlier period and during the founding of the organisation, which helps confirm that born globals management tends to have a more aggressive strategic behaviour towards foreign and/or national networks during the first years of business.

The main implication of the present study is the confirmation that the founder is indeed a key player in the strategic behaviour of the born globals. On the other hand, the environment also presents itself as an almost as important factor, since it motivates the behaviour of the entrepreneur.

The main limitation of the study was the limited sampling researchers had access to. In addition to this limitation we could also include the absence of an interview with the founder of alpha.

A suggestion for future studies would be to analyse specifically how the strategic formulation within the organisation occurs and how this affects the process of internationalisation over the years, verifying the role of stakeholders in the company strategy in relation to the other actors of the organisation. 


\section{References}

Acedo, F.J. and Jones, M.V. (2007) 'Speed of internationalization and entrepreneurial cognition: insights and a comparison between international new ventures, exporters and domestic firms', Journal of World Business, Vol. 42, No. 3, pp.236-252.

Bardin, L. (2011) Análise de Conteúdo, 2nd ed., Edições 70, São Paulo.

Carneiro, J.M.T. and Dib, L.A. (2007) 'Avaliação comparativa do escopo descritivo e explanatório dos principais modelos de internacionalização de empresas', Internext, Vol. 2, No. 1, pp.1-25.

Coviello, N.E. and Munro, H.J. (1994) 'Growing the entrepreneurial firm: networking for international market development', European Journal of Marketing, Vol. 29, No. 7, pp.49-61.

Dib, L.A.R. (2008) O Processo de Internacionalização de Pequenas e Médias Empresas e o Fenômeno Born Global: Estudo do Setor de Software no Brasil, Doctorate level, Universidade Federal do Rio de Janeiro, Rio de Janeiro.

Drucker, P. (1987) Inovação e Espirito Empreendedor (Entrepreneurship): Prática e Princípios, Pioneira, São Paulo.

Dul, J.M.T. and Hak, T. (2008) Case Study Methodology in Business Research, Elsevier, Massachusetts.

Falize, M. and Coeurderoy, R. (2012) The Network Approach to Rapid Internationalization among Born-Global and Born-Again Global Firms: The Case of the Global Innovation Network, Louvain School of Management Research Institute, Lyon.

Gerschewski, S., Rose, E.L. and Lindsay, V.J. (2015) 'Understanding the drivers of international performance for born global firms: an integrated perspective', Journal of World Business, Vol. 50, No. 3, pp.558-575.

Italian Trade Agency (2016) [online] http://actea.ice.it/studi.aspx (accessed 15 April 2016).

Johanson, J. and Vahlne, J-e. (2009) 'The Uppsala internationalization process model revisited: from liability of foreignness to liability of outsidership', Journal of International Business Studies, Vol. 40, pp.1411-1431.

Knight, G. and Cavusgil, S.T. (2009) Born Global Firms: A New International Enterprise, Business Expert Press, New York.

Kontinen, T. and Ojala, A. (2011) 'Network ties in the international opportunity recognition of family SMEs', International Business Review, Vol. 20, No. 4, pp.440-453.

Luostarinen, R. (1994) Internationalization of Finnish Firms and their Response to Global Challenges, World Institute for Development Economics Research.

Martin, J. and Oscar, M.M. (2015) 'The incremental expansion of born internationals: a comparison of new and old born internationals', International Business Review, Vol. 24, No. 3, pp.476-496.

Ministério do Desenvolvimento, Indústria e Comércio Exterior (2014) Ministério do Desenvolvimento, Indústria e Comércio Exterior [online] http://www.mdic.gov.br/sitio/ (accessed 15 April 2016).

Muralidharan, E. and Pathak, S. (2016) 'Informal institutions and international entrepreneurship', International Business Review, Vol. 26, No. 2, pp.288-302.

Prange, C. and Verdier, S. (2011) 'Dynamic capabilities, internationalization processes and performance', Journal of World Business, Vol. 46, No. 1, pp.126-133.

Rennie, M.W. (1993) 'Born global', The McKinsey Quarterly, Autumn, No. 4, pp.45-52.

Reuber, A.R. and Fischer, E. (1997) 'The influence of the management team's international experience on the internationalization', Journal of International Business Studies, Vol. 28, No. 4, pp.807-825.

Scattolin, S. (2012) Aziende Born Global e Loro Determinanti, Masters level, University Ca' Foscari, Venice.

Sharma, D.D. and Blomstermo, A. (2003) 'The internationalization process of born globals: a network view’, International Business Review, Vol. 12, No. 6, pp.739-753. 